\title{
Bacillus aidingensis sp. nov., a moderately halophilic bacterium isolated from Ai-Ding salt lake in China
}

\author{
Correspondence \\ Yanhe Ma \\ mayanhe@im.ac.cn
}

\author{
Yanfen Xue, ${ }^{1}$ A. Ventosa, ${ }^{2}$ Xiaowei Wang, ${ }^{1}$ Peigen Ren, ${ }^{1}$ Peijin Zhou $^{1}$ \\ and Yanhe $\mathrm{Ma}^{1}$ \\ ${ }^{1}$ State Key Laboratory of Microbial Resources, Institute of Microbiology, Chinese Academy of \\ Sciences, Beijing 100101, PR China \\ ${ }^{2}$ Department of Microbiology and Parasitology, Faculty of Pharmacy, University of Sevilla, 41012 \\ Sevilla, Spain
}

\begin{abstract}
A Gram-positive, halophilic bacterium was isolated from a sediment sample from Ai-Ding salt lake in China. The isolate, designated strain $17-5^{\top}$, grew at salinities of $8-33 \%(\mathrm{w} / \mathrm{v}) \mathrm{NaCl}$ (optimally at $12 \%, w / v)$. The genomic DNA G $+\mathrm{C}$ content of strain $17-5^{\top}$ was $48.1 \mathrm{~mol} \%$. The predominant isoprenoid quinone was $\mathrm{MK}-7\left(\mathrm{H}_{2}\right)$ and the cell-wall peptidoglycan contained mesodiaminopimelic acid. The major polar lipids were diphosphatidylglycerol and an unidentified glycolipid. The major cellular fatty acids were anteiso- $C_{15: 0}$, anteiso- $C_{17: 0}$, iso- $C_{16: 0}$ and $C_{16: 0 \text {. }}$. Phylogenetic analysis based on 16S rRNA gene sequences showed that strain $17-5^{\top}$ was a member of the genus Bacillus, being most closely related to Bacillus qingdaonensis JCM $14087^{\top}$ (96.0\% sequence similarity) and Bacillus salarius DSM $16461^{\top}(95.6 \%)$. The levels of $16 \mathrm{~S}$ rRNA gene sequence similarity with respect to other Bacillus species were less than $91.7 \%$. Comparative analysis of the 16S rRNA gene sequence data, chemotaxonomy and phenotypic features of the novel isolate and related species of Bacillus indicated that strain $17-5^{\top}$ represents a novel species within the genus Bacillus, for which the name Bacillus aidingensis sp. nov. is proposed. The type strain is $17-5^{\top}$ (=CGMCC $\left.1.3227^{\top}=\mathrm{DSM} 18341^{\top}\right)$.
\end{abstract}

Moderately halophilic bacteria that grow optimally in media containing 3-15\% (w/v) NaCl are widely distributed throughout various types of saline environments, such as salt lakes, salterns and salty foods (Ventosa et al., 1998). Lake Ai-Ding $\left(89^{\circ} 10^{\prime} 32^{\prime \prime}-83^{\circ} 54^{\prime} 32^{\prime \prime}\right.$ E $42^{\circ} 32^{\prime} 10^{\prime \prime}-42^{\circ} 49^{\prime}$ $13^{\prime \prime} \mathrm{N}$ ) is a typical chloride-sulphate saline lake with a neutral $\mathrm{pH}$ and a salt concentration of $20-26 \%(\mathrm{w} / \mathrm{v})$. Previous studies on the microbial diversity of Ai-Ding salt lake have demonstrated the presence of a variety of halophilic micro-organisms (Cui et al., 2006a, b; Ren \& Zhou, 2005a, b). In this paper, we describe a novel moderately halophilic bacterium, designated strain $17-5^{\mathrm{T}}$, isolated from Lake Ai-Ding. Phenotypic and chemotaxonomic characteristics, as well as data from a phylogenetic analysis based on $16 \mathrm{~S}$ rRNA gene sequence comparisons, showed that strain $17-5^{\mathrm{T}}$ represents a novel species within the genus Bacillus.

The sample collection/treatment and the enrichment and isolation of strain $17-5^{\mathrm{T}}$ were performed as described by

The GenBank/EMBL/DDBJ accession number for the 16S rRNA gene sequence of strain $17-5^{\top}$ is DO504377.

Photomicrographs of cells of strain $17-5^{\top}$ are available as supplementary material with the online version of this paper.
Ren \& Zhou (2005a). Strain $17-5^{\mathrm{T}}$ was routinely grown on HM medium (Ventosa et al., 1982) containing $12 \%(\mathrm{w} / \mathrm{v})$ $\mathrm{NaCl}$ instead of $17.8 \% \mathrm{NaCl}$ (modified HM medium). Cellular morphology was examined using light microscopy and transmission electron microscopy. Gram staining was performed as described by Gerhardt et al. (1981), in parallel with the $\mathrm{KOH}$ test (Gregersen, 1978). Motility was determined in wet mounts by using phase-contrast microscopy; flagella were demonstrated using negative staining (Kodaka et al., 1982) and transmission electron microscopy. The $\mathrm{NaCl}$, temperature and $\mathrm{pH}$ ranges for growth, the utilization of carbon and energy sources (added at $0.5 \%, \mathrm{w} / \mathrm{v}$ ) and the hydrolysis of starch, casein, gelatin and Tweens 20, 40, 60 and 80 were determined as described previously (Ren \& Zhou, 2005a). General biochemical tests (including those for nitrate reduction, urease activities, $\mathrm{H}_{2} \mathrm{~S}$ production, catalase and oxidase activities, citrate utilization and indole production and the Voges-Proskauer reaction and the methyl red test) were performed as described by Smibert \& Krieg (1981). Susceptibility to antibiotics was tested by spreading bacterial suspensions on agar plates containing modified HM medium, placing antibiotic-impregnated paper discs ( $7 \mathrm{~mm}$ in diameter and $1 \mathrm{~mm}$ in thickness) on the agar 
surface, incubating the plates for $48 \mathrm{~h}$ and checking for a clear zone of growth inhibition around each disc (representing antibiotic sensitivity). Strain $17-5^{\mathrm{T}}$ showed an obligatory halophilic response, growing in the presence of $8-33 \%(\mathrm{w} / \mathrm{v}) \mathrm{NaCl}$. Cells of strain $17-5^{\mathrm{T}}$ were endospore-forming, motile, short rods with peritrichous flagella (see Supplementary Fig. S1, available in IJSEM Online). On modified HM medium strain $17-5^{\mathrm{T}}$ formed creamy white, slightly centre-convex and circular colonies after cultivation at $37^{\circ} \mathrm{C}$ for $24 \mathrm{~h}$. Additional phenotypic properties are presented in the species description and in Table 1.

Preparation of the cell wall and determination of the peptidoglycan composition were performed by using the methods described by Schleifer \& Kandler (1972), but with the modification that TLC on cellulose sheets was used instead of paper chromatography. Respiratory quinones were extracted according to the method of Collins et al. (1977) and were analysed by using reversed-phase HPLC (Groth et al., 1996). Polar lipids were extracted and identified by using one-dimensional TLC followed by spraying with the appropriate detection reagents (Kates, 1986). Cellular fatty acids were extracted, methylated and analysed by GC using the standard Sherlock MIDI
(Microbial Identification) system (Sasser, 1990; Kämpfer \& Kroppenstedt, 1996). The genomic DNA G + C content was determined by means of the thermal denaturation method, according to Marmur \& Doty (1962). Strain $17-5^{\mathrm{T}}$ contained meso-diaminopimelic acid as the diagnostic diamino acid in the cell-wall peptidoglycan. The polar lipid extract contained diphosphatidylglycerol and an unidentified glycolipid. The major isoprenoid quinone of strain $17-5^{\mathrm{T}}$ was MK-7 $\left(\mathrm{H}_{2}\right)$. The cellular fatty acids of strain $17-5^{\mathrm{T}}$ were as follows: anteiso- $\mathrm{C}_{15: 0}(30.6 \%), \mathrm{C}_{16: 0}$ $(16.4 \%)$, anteiso- $\mathrm{C}_{17: 0}(16.2 \%)$, iso- $\mathrm{C}_{16: 0}(15.1 \%)$, iso$\mathrm{C}_{15: 0}(6.8 \%)$, iso- $\mathrm{C}_{14: 0}(4.7 \%)$, iso- $\mathrm{C}_{17: 0}(4.7 \%), \mathrm{C}_{15: 0}$ $(2.9 \%)$ and $\mathrm{C}_{17: 0}(2.4 \%)$. These chemotaxonomic features of strain $17-5^{\mathrm{T}}$ were typical of those found in members of the genus Bacillus (Priest et al., 1988; Heyrman et al., 2004, 2005; Albert et al., 2005; Wieser et al., 2005; Lim et al., $2006 \mathrm{a}, \mathrm{b})$. The genomic DNA G $+\mathrm{C}$ content of strain $17-5^{\mathrm{T}}$ was $48.1 \mathrm{~mol} \%$. This value is within the range for the genus Bacillus.

The 16S rRNA gene of strain $17-5^{\mathrm{T}}$ was amplified by PCR with universal primers, as described previously (Duckworth et al., 1996). The almost-complete nucleotide sequence (1562 bp) was determined by direct sequencing and was compared with $16 \mathrm{~S}$ rRNA gene sequences available

Table 1. Differential features for strain $17-5^{\top}$ (Bacillus aidingensis sp. nov.) with respect to the two most closely related Bacillus species

+ , Positive; -, negative; ND, no data available.

\begin{tabular}{|c|c|c|c|}
\hline Characteristic & Strain $17-5^{T_{\star}}$ & B. qingdaonensis JCM $14087^{\mathrm{T}} \dagger$ & B. salarius DSM $16461^{\mathrm{T}} \ddagger$ \\
\hline Flagellation & + & - & - \\
\hline Endospore formation & + & - & + \\
\hline Optimum pH & 7.2 & 9.0 & 8.0 \\
\hline Temperature range $\left({ }^{\circ} \mathrm{C}\right)$ & $22-44$ & $25-45$ & $15-40$ \\
\hline Optimum temperature $\left({ }^{\circ} \mathrm{C}\right)$ & 37 & 37 & 30 \\
\hline Optimum $\mathrm{NaCl}$ conc. $(\%, \mathrm{w} / \mathrm{v})$ & 12 & 12 & $10-12$ \\
\hline Oxidase & - & - & + \\
\hline \multicolumn{4}{|l|}{ Acid production from: } \\
\hline Sucrose & - & + & $\mathrm{ND}$ \\
\hline D-Xylose & - & + & + \\
\hline D-Lactose & - & + & + \\
\hline Major fatty acids (\% of total) & $\begin{array}{c}\text { anteiso- } \mathrm{C}_{15: 0} \text { (30.6), anteiso- } \mathrm{C}_{17: 0} \\
(16.2), \mathrm{C}_{16: 0}(16.4) \text {, iso- } \mathrm{C}_{16: 0} \\
(15.1)\end{array}$ & $\begin{array}{c}\text { anteiso- } \mathrm{C}_{15: 0}(34.7), \text { anteiso- } \\
\mathrm{C}_{17: 0}(21.4), \text { iso- } \mathrm{C}_{16: 0}(13.9) \\
\mathrm{C}_{16: 0}(7.7)\end{array}$ & $\begin{array}{c}\text { anteiso- } \mathrm{C}_{15: 0}(53.1) \text {, anteiso- } \\
\mathrm{C}_{17: 0}(18.6), \text { iso- } \mathrm{C}_{15: 0}(8.9), \\
\text { iso- }_{16: 0}(6.6)\end{array}$ \\
\hline Major menaquinone & $\mathrm{MK}-7\left(\mathrm{H}_{2}\right)$ & MK-7 $\left(\mathrm{H}_{2}\right)$ & MK-7 \\
\hline DNA G $+C$ content $(\mathrm{mol} \%)$ & 48.1 & 48.0 & 43.0 \\
\hline
\end{tabular}

${ }^{\star}$ Data from this study.

$\dagger$ Data from Wang et al. (2007).

\$Data from Lim et al. (2006b). 
in the GenBank database, using the BLAST program. Multiple alignment with closely related species was performed using the CLUSTAL $\mathrm{w}$ program (Thompson et al., 1994). Ambiguous and unalignable bases were omitted manually and then the phylogenetic trees were constructed using the neighbour-joining, minimum-evolution and maximum-parsimony methods in MEGA, version 3.1 (Kumar et al., 2004). The robustness of the resultant tree topology was evaluated by means of bootstrap resampling analysis with 1000 replicates. The 16S rRNA gene sequence analysis showed that strain $17-5^{\mathrm{T}}$ was phylogenetically related to members of the family Bacillaceae and belonged within the phyletic group classically defined as the genus Bacillus. Strain $17-5^{\mathrm{T}}$ was most closely related to Bacillus qingdaonensis JCM $14087^{\mathrm{T}}$ and Bacillus salarius DSM $16461^{\mathrm{T}}$, with 96.0 and $95.6 \%$ sequence similarity, respectively. The sequence similarities with respect to other known species of the genus Bacillus were much lower $(<91.7 \%)$. The neighbour-joining phylogenetic tree (Fig. 1) also showed that strain $17-5^{\mathrm{T}}$ formed a coherent cluster with $B$. qingdaonensis JCM $14087^{\mathrm{T}}$ and $B$. salarius DSM $16461^{\mathrm{T}}$ within the genus Bacillus and was distantly related to other members of the genus. Similar tree topologies were observed when other algorithms were used. The high levels of sequence similarity divergence $(>4.0 \%)$ with respect to the type strains of the known species of the genus Bacillus suggested that strain $17-5^{\mathrm{T}}$ represents a novel taxon within the genus Bacillus (Stackebrandt et al., 2002).

The characteristics that serve to differentiate strain $17-5^{\mathrm{T}}$ from related Bacillus species are summarized in Table 1. The differences in some features, such as nitrate reduction, $\mathrm{H}_{2} \mathrm{~S}$ production, oxidase and urease activities, salt range for growth, optimal $\mathrm{pH}$ for growth, and acid production from xylose and lactose, as well as the fatty acid composition, can be used to distinguish this strain from phylogenetically related taxa (Table 1). Therefore, on the basis of the taxonomic data presented here, strain $17-5^{\mathrm{T}}$ represents a novel species of the genus Bacillus, for which the name Bacillus aidingensis sp. nov. is proposed.

\section{Description of Bacillus aidingensis sp. nov.}

Bacillus aidingensis (ai.din.gen'sis. N.L. masc. adj. aidingensis from Lake Ai-Ding, a saline lake in China).

Cells are Gram-positive, aerobic, short rods 0.2-0.4 × 1.3$2.5 \mu \mathrm{m}$ in size and motile by means of peritrichous flagella. Ellipsoidal endospores are formed subterminally or centrally. Colonies are creamy white, slightly centre-convex, circular, 4-5 $\mathrm{mm}$ in diameter and have regular margins after cultivation at $37{ }^{\circ} \mathrm{C}$ on modified HM medium for $24 \mathrm{~h}$. Growth occurs at temperatures in the range $22-44{ }^{\circ} \mathrm{C}$ (optimally at $37{ }^{\circ} \mathrm{C}$ ) and at $\mathrm{NaCl}$ concentrations in the range $8-33 \%(w / v)$ (optimally at $12 \%)$. No growth occurs

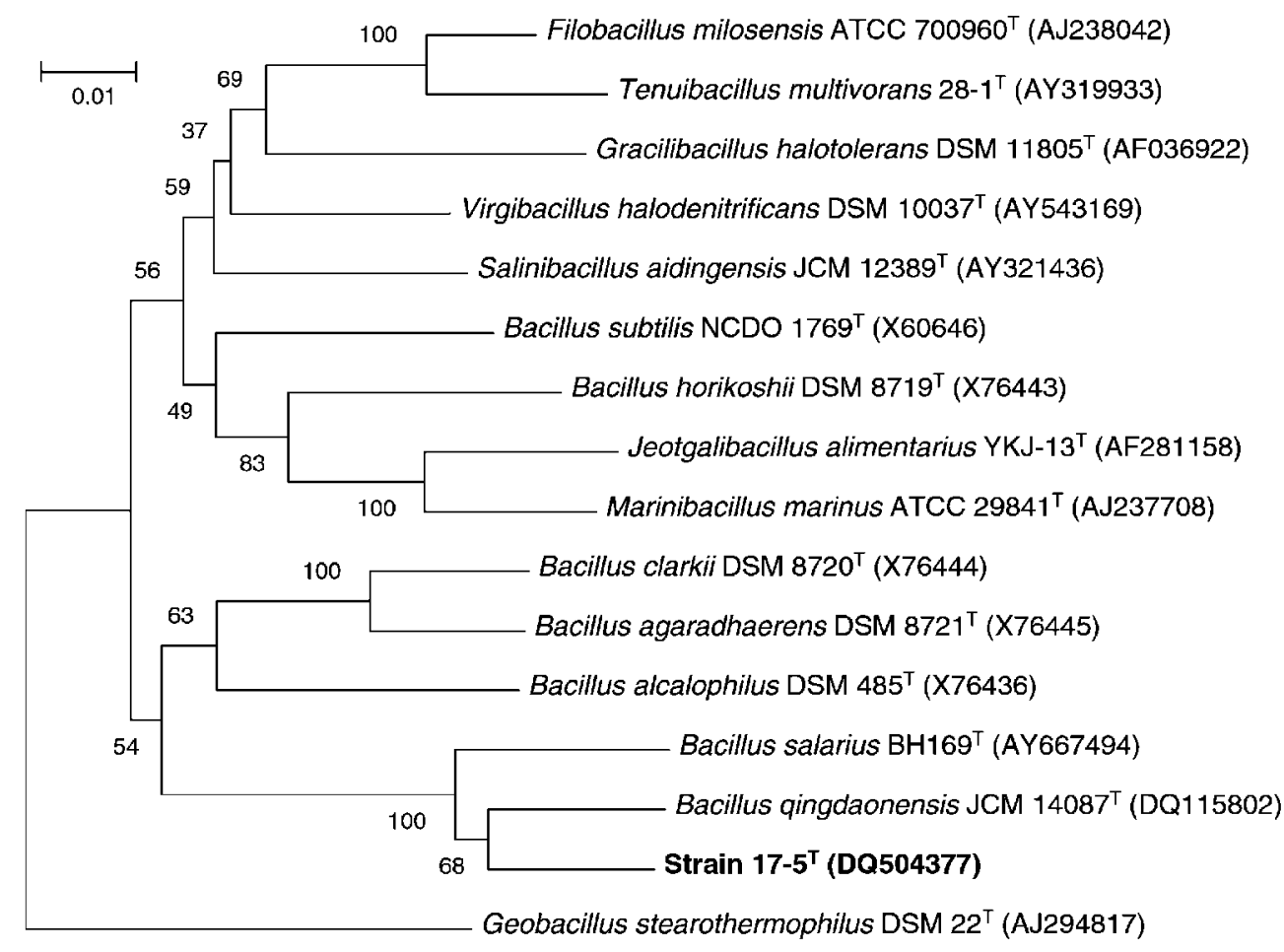

Fig. 1. Neighbour-joining phylogenetic tree, based on $16 \mathrm{~S}$ rRNA gene sequences, showing the relationships among strain $17-5^{\top}$ (Bacillus aidingensis sp. nov.) and related species. Numbers at nodes are bootstrap percentages, based on an analysis of 1000 resampled datasets. Bar, $1 \%$ sequence divergence. 
in the absence of $\mathrm{NaCl}$. $\mathrm{pH}$ range for growth is $6.0-9.5$ (optimum, pH 7.2). Positive in the Voges-Proskauer reaction and for catalase, gelatin and aesculin hydrolysis, nitrate reduction and $\mathrm{H}_{2} \mathrm{~S}$ production, but negative in the methyl red test and for oxidase, urease, DNase, phosphatase, $\mathrm{NH}_{3}$ production and hydrolysis of casein, starch, cellulose and Tweens 20,40,60 and 80. The following compounds are utilized as sole carbon and energy sources: D-glucose, D-mannose, D-galactose, L-sorbose, D-sorbose, D-fructose, lactose, sucrose, maltose, cellobiose, melibiose, trehalose, raffinose, melezitose, D-mannitol, inositol, dulcitol, erythritol, glycerol, inulin and salicin. L-Rhamnose, $\mathrm{D}$-arabinose and D-xylose are not used as carbon sources. Acid is produced from D-glucose, D-galactose, D-mannose, D-fructose, maltose, cellobiose, trehalose, D-mannitol and glycerol, but not from L-sorbose, D-sorbose, raffinose, melezitose, lactose, sucrose, melibiose, dulcitol, erythritol, inulin or salicin. Sensitive to the following antibiotics ( $\mu$, unless indicated otherwise): ampicillin (10), oxacillin (1), penicillin G (10 U), cefazolin (30), tetracycline (30), chloramphenicol (30), clindamycin (2), erythromycin (15), sulfamethoxazole (300), nitrofurantoin (300), norfloxacin (10), vancomycin (30), ciprofloxacin (5), clarithromycin (15), kanamycin (30), leucomycin (15), acetylspiramycin (15), rifampicin (5), spectinomycin (100), ampicillin/sulbactam (10/10), azithromycin (15), josamycin (15), medicamycin (15), bacitracin (0.04 U) and novobiocin (5). Resistant to the following antibiotics ( $\mu \mathrm{g}$, unless indicated otherwise): gentamicin (10), streptomycin (10), tobramycin (10), neomycin (30) and polymyxin B (300 U). Major polar lipids are diphosphatidylglycerol and an unidentified glycolipid. Major fatty acids are anteiso$\mathrm{C}_{15: 0}, \mathrm{C}_{16: 0}$, anteiso- $\mathrm{C}_{17: 0}$, iso- $\mathrm{C}_{16: 0}$ and iso- $\mathrm{C}_{15: 0}$. The diagnostic diamino acid in the cell-wall peptidoglycan is meso-diaminopimelic acid. The predominant menaquinone is MK-7 $\left(\mathrm{H}_{2}\right)$. The genomic DNA G $+\mathrm{C}$ content of the type strain is $48.1 \mathrm{~mol} \%\left(T_{\mathrm{m}}\right)$.

The type strain, $17-5^{\mathrm{T}}\left(=\mathrm{CGMCC} 1.3227^{\mathrm{T}}=\mathrm{DSM} 18341^{\mathrm{T}}\right)$, was isolated from a sediment sample from Lake Ai-Ding, a salt lake in Xin-Jiang Province, China.

\section{Acknowledgements}

This work was supported by grants from the Chinese Academy of Sciences (Knowledge Innovation Program, KSCX2-YW-G-011) and the Ministry of Science and Technology of China (863 programs: 2006AA020201 and 2007AA021306; 973 programs: 2003CB716001 and 2007CB707801).

\section{References}

Albert, R. A., Archambault, J., Rosselló-Mora, R., Tindall, B. J. \& Matheny, M. (2005). Bacillus acidicola sp. nov., a novel mesophilic, acidophilic species isolated from acidic Sphagnum peat bogs in Wisconsin. Int J Syst Evol Microbiol 55, 2125-2130.

Collins, M. D., Pirouz, T., Goodfellow, M. \& Minnikin, D. E. (1977). Distribution of menaquinones in actinomycetes and corynebacteria. $J$ Gen Microbiol 100, 221-230.
Cui, H. L., Tohty, D., Zhou, P. J. \& Liu, S. J. (2006a). Halorubrum lipolyticum sp. nov. and Halorubrum aidingense sp. nov., isolated from two salt lakes in Xin-Jiang, China. Int J Syst Evol Microbiol 56, 16311634.

Cui, H. L., Yang, Y., Dilbr, T., Zhou, P. J. \& Liu, S. J. (2006b). Biodiversity of halophilic archaea isolated from two salt lakes in XinJiang region of China. Wei Sheng Wu Xue Bao 46, 171-176 (in Chinese).

Duckworth, A. W., Grant, W. D., Jones, B. E. \& van Steenbergen, R. (1996). Phylogenetic diversity of soda lake alkaliphiles. FEMS Microbiol Ecol 19, 181-191.

Gerhardt, P., Murray, R. G. E., Costilow, R. N., Nester, E. W., Wood, W. A., Krieg, N. R. \& Phillips, G. B. (editors) (1981). Manual of Methods for General Bacteriology. Washington, DC: American Society for Microbiology.

Gregersen, T. (1978). Rapid method for distinction of Gram-negative from Gram-positive bacteria. Eur J Appl Microbiol Biotechnol 5, 123127.

Groth, I., Schumann, P., Weiss, N., Martin, K. \& Rainey, F. A. (1996). Agrococcus jenensis gen. nov., sp. nov., a new genus of actinomycetes with diaminobutyric acid in the cell wall. Int J Syst Bacteriol 46, 234239.

Heyrman, J., Vanparys, B., Logan, N. A., Balcaen, A., Rodriguez-Diaz, M., Felske, A. \& De Vos, P. (2004). Bacillus novalis sp. nov., Bacillus vireti sp. nov., Bacillus soli sp. nov., Bacillus botaviensis sp. nov. and Bacillus drentensis sp. nov., from the Drentse A grasslands. Int J Syst Evol Microbiol 54, 47-57.

Heyrman, J., Rodriguez-Diaz, M., Devos, J., Felske, A., Logan, N. A. \& De Vos, P. (2005). Bacillus novalis sp. nov., Bacillus arvi sp. nov. and Bacillus humi sp. nov., isolated from soil. Int J Syst Evol Microbiol 55, 111-117.

Kämpfer, P. \& Kroppenstedt, R. M. (1996). Numerical analysis of fatty acid patterns of coryneform bacteria and related taxa. Can J Microbiol 42, 989-1005.

Kates, M. (1986). Techniques of Lipidology, 2nd edn. Amsterdam: Elsevier.

Kodaka, H., Armfield, A. Y., Lombard, G. L. \& Dowell, V. R., Jr (1982). Practical procedure for demonstrating bacterial flagella. J Clin Microbiol 16, 948-952.

Kumar, S., Tamura, K. \& Nei, M. (2004). MEGA3: integrated software for molecular evolutionary genetics analysis and sequence alignment. Brief Bioinform 5, 150-163.

Lim, J.-M., Jeon, C. O. \& Kim, C.-J. (2006a). Bacillus taeanensis sp. nov., a halophilic Gram-positive bacterium from a solar saltern in Korea. Int J Syst Evol Microbiol 56, 2903-2908.

Lim, J.-M., Jeon, C. O., Lee, S.-M., Lee, J.-C., Xu, L.-H., Jiang, C.-L. \& Kim, C.-J. (2006b). Bacillus salarius sp. nov., a halophilic sporeforming bacterium isolated from a salt lake in China. Int J Syst Evol Microbiol 56, 373-377.

Marmur, J. \& Doty, P. (1962). Determination of the base composition of deoxyribonucleic acid from its thermal denaturation temperature. $J$ Mol Biol 5, 109-118.

Priest, F. G., Goodfellow, M. \& Todd, C. (1988). A numerical classification of the genus Bacillus. J Gen Microbiol 134, 1847-1882.

Ren, P.-G. \& Zhou, P.-J. (2005a). Tenuibacillus multivorans gen. nov., sp. nov., a novel moderately halophilic bacterium isolated from saline soil in Xin-Jiang, China. Int J Syst Evol Microbiol 55, 95-99.

Ren, P.-G. \& Zhou, P.-J. (2005b). Salinibacillus aidingensis gen. nov., sp. nov. and Salinibacillus kushneri sp. nov., moderately halophilic bacteria isolated from a neutral saline lake in Xin-Jiang, China. Int $J$ Syst Evol Microbiol 55, 949-953. 
Sasser, M. (1990). Identification of bacteria by gas chromatography of cellular fatty acids, MIDI Technical Note 101. Newark, DE: MIDI Inc.

Schleifer, K. H. \& Kandler, O. (1972). Peptidoglycan types of bacterial cell walls and their taxonomic implications. Bacteriol Rev 36, 407477.

Smibert, R. M. \& Krieg, N. R. (1981). General characterization. In Manual of Methods for General Microbiology, pp. 409-443. Edited by P. Gerhardt, R. G. E. Murray, R. N. Costilow, E. W. Nester, W. A. Wood, N. R. Krieg \& G. B. Phillips. Washington, DC: American Society for Microbiology.

Stackebrandt, E., Fredericksen, W., Garrity, G. M., Grimont, P. A., Kämpfer, P., Maiden, M. C., Nesme, X., Rosselló-Mora, R., Swings, J. \& other authors (2002). Report of the ad hoc committee for the reevaluation of the species definition in bacteriology. Int J Syst Evol Microbiol 52, 1043-1047.
Thompson, J. D., Higgins, D. G. \& Gibson, T. J. (1994). ClUSTAL W: improving the sensitivity of progressive multiple sequence alignment through sequence weighting, position-specific gap penalties and weight matrix choice. Nucleic Acids Res 22, 4673-4680.

Ventosa, A., Quesada, E., Rodriguez-Valera, F., Ruiz-Berraquero, F. \& Ramos-Cormenzana, A. (1982). Numerical taxonomy of moderately halophilic Gram-negative rods. J Gen Microbiol 128, 1959-1968.

Ventosa, A., Nieto, J. J. \& Oren, A. (1998). Biology of moderately halophilic aerobic bacteria. Microbiol Mol Biol Rev 62, 504-544.

Wang, Q. F., Li, W., Liu, Y. L., Cao, H. H., Li, Z. \& Guo, G. Q. (2007). Bacillus qingdaonensis sp. nov., a moderately haloalkaliphilic bacterium isolated from a crude sea-salt sample collected near Qingdao in eastern China. Int J Syst Evol Microbiol 57, 1143-1147.

Wieser, M., Worliczek, H., Kämpfer, P. \& Busse, H.-J. (2005). Bacillus herbersteinensis sp. nov. Int J Syst Evol Microbiol 55, 2119-2123. 